\title{
GRIMINAL LAW - HOMICIDE - MENS REA - OBJECTIVE OR SUBJECTIVE TESTS
}

Regina s. Ward', a recent decision of the Court of Criminal Appeal, is a uost signifieant case which invites an examination of the position of mens rea in the law of murder." The appellant W/ard, who was proved to be a man of sub-normal intelligence, was convicted for murdering the eighteen-month old child of the woman with whom he was cohabiting. The case arose in the following circumstances. One evening the appellant Ward had come home after work, and began to mend the bed, after placing the child on a mattress on the floor in the same room. As he began to hammer the child began to cry. The child's crying aggravated Ward's already nervous state of mind, which was due to tiredness and to ulcer pains. He lost his temper, picked the child up, and shook her "with full force", intending only to quiet her, and not to kill or cause her grievous bodily harm. When he placed the child on the mattress "she dropped forwards and sideways", and her mother, who had been absent only fifteen minutes, returned to find het dead. The couple were in panic and buried the child in a slag heap where it remained about twentymonths before being discovered. In the medical opinion adduced by the prosecution the two fractures in the akull were not in themselves enough to cause death, but death was probably due to asphyxia.

At the trial Pilcher J. directed the jury in these ternis:

If. when he did the set which he did do, he must as a reasonable man have contemplated

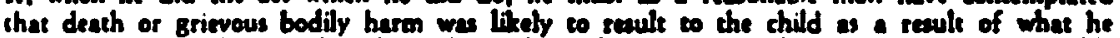
did do, then, ... he he guiley of murdet. If, on the exher hend, he could not at a reasonsble man have contemplated that death would result in conenguence of what he did, then he is guilty of memalaughter. ${ }^{3}$

The jury returned a verdict of murder, and the appeal was taken on grounds of misclirection as to the proper test to be applied in distinguishing between murder and manslaughter. The appellant's counsel contended that the primary matter to be considered by the jury was the accused's subjective state of mind, and that if the jury should have a reasonable doubt as to the accused's intention to kill or to cause grievous bodily harm, then the verdiet should be manslaughter.

Lord Goddard rejected this submission, and lauded the trial judge's direc. tion as "an unimpeachable summing-up, and it is a direction which has been given to one's own knowledge in scores of cases," not one of which, however, does he cire his judgment. The learned Lord Chief Justice substantially disDosed of the appeal in one sentence:

Of course, the eat must be applied to all alike, and the only measure that can be broughe to ores in these matters is what a resuonabie man would or would not rontemplete."

'[1956] I W.L.R. 423.

aThis comment deals with the Werd cese in the light of exnerl principle. A comment by by S. Prevease in [1956] Crim. I. R. deale with the affect of the Werd can in particulnt especes of the law:

it 1. 423, suppr.

$\therefore-\therefore: s, s 25:$. 
It is clear from the foregoing that the jury had no opportunity to consider the accused's actual state of mind; it was common ground to both counsel as the trial that the accused was nor a reasonable man. and yet regard was had only to what the reasonable man would or would not have contemplated in tine circumstances.

It is respectfully submitted that the $W$ ard case is a departure from principle and was wrongly decided. There is abundant authority holding that no man should be convicted of murder unless he has a subjective guilty mind, but none of these cases were discussed or even referred to in the $W$ ard cose. In one of the carly cases, Regina v. Vamplew", decided in 1863, the accused was much closer to having a guilty mind than Ward was in the instant case. yet Pollock C.B. directed the jury to consider the accused's state of mind: the jury did so and found him guilty of manslaughter. The report of the case nores that:

The Chief Boron mid, the crimen of murdor and monthughter were in come inerances

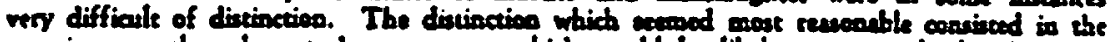
consciousness that the ea dose wa one which would be likely to canen deseh. No one, however, could commit murder without that conciousanen. The jury must be eatified before they could find the prisoner cuilty, that whe was conecious and that her eet wes deliberets. They must be eatiofied that abe lued errived at that merusity of inellect which was neceseary condition of the crime charged.

In Regina v. Bubb", a case where a woman wes charged with starving inet step-child to death, the jury were directed in these terms:

And bese it becomes secounsy to explain what in meent by the exprescion malicious . . . You will cherefore probably conider thes the quection resalves irelf into this-Did thr pritonet contumplece by the courue she purpued, the dath of the child? If ahe ded. and death was caused by the coure ele purvued, then she is suiley of murder. But if you ere not satufied that ahe contempleted the death of the child, then clthough guily of a culpebie andect of dury, ut would emount only to the crime of mansiaughter.

Baron Bramwell's direction in Rex v. Horsey' is in the same vein: the accused must have been conscious that his aet would cause death or grevious bodily harm in order to have malice aforethought. In all these cases there is no trace of an objective test. It is true that the objective test has been applied in some cases to find malice aforechought. $R$. v. Whitmarsh," $R$. v. Bottomlev" and $R$. v. Lumley, ${ }^{10}$ were cases where the objective test was applied, and the last was before the Court in the Ward case. But in every one of these cases the aceused persons had performed felonious operations which were faral, and they could have been convieted of murder had the then existing doctrine of constructive malice been applied. $R$. v. Rymell, 21954 case, may be of support for the inscant case, aince both the facts of the case and the direction given the jury were very similat. The jury found the secused guilty of murder. However, the Court of Criminal Appeal subutituted a verdict of manslaughter on 2 question of causation. It is submitted that anything that may have been

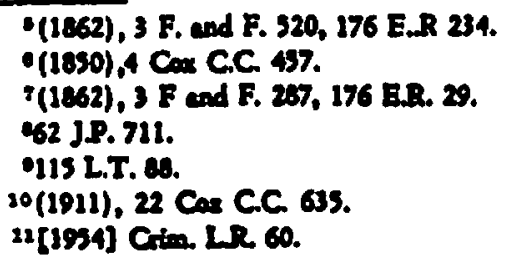

(1862), 3 F. and F. 320, 176 E.R 234.

- (1850), 4 Con C.C. 457.

?(1862), 3 F and F. 267, 176 ER. 29.

62 JP. 711.

$\bullet 115$ L.T. 6.

10(1911), 22 Cas CC 635.

21[19s4] Cim LR 60. 
done in Rymrll was undone in the ame year, in $R$. v. Lachinsky. : The case involved a homicide done by a man of sub-nomal intelligence, and the trial judge directed the jury that "if they were atisfied that, owing to the feeblemindedness of the accused, he was incapable of forming the intention to cause grievous bodily harm, they must find him guilty of manslaughter." The jury returned a verdice of murder, and the Court of Criminal Appeal composed of Lord Goddard C.J., Byrne and Tucker J.J. approved the direction as "absolurely correct." This case apparendly was not before the court in the $W$ ard case although Lord Goddard sat on both cases.

In the ordinary case where the accused takes the stand, the jury may accept his evidence, or refuse to believe him. In the latter case they will consider the evidence, and to it they will apply she presumption that every man intends the natural consequences of his act, in order to find his intencion. In the instant case, immediately after directing the jury on the objective test, Pileher J. stated:

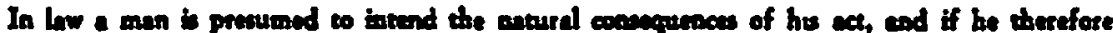

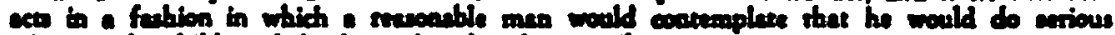

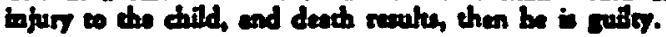

It is submitted that this sentence together with the previous one giving the objective test (quoted supra) clearly indicate that the leamed trial judge is confusing a matter of evidence with a substantive rule of law. The presumption of natural consequences is treated as an irrebutrable legal presumption, fot its application is deemed mandatory. The true pocition was set out by Denning L.J. in Hosegood v. Hosegood" a statement of the law which was adopted in tolo by the Ontario Court of Appeal in Regine v. Giannotti." Denning L.J states:

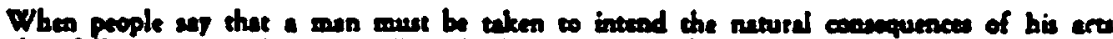

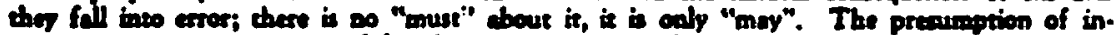

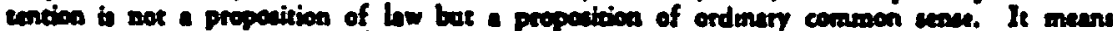

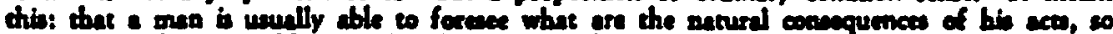
is is a sule ressonsble to infer that be did formen then and intend them. But while it is an inference which may be drewa it is not cas thet anuse be drawn. If en all the fects of the cone it is noe a cosrect inference then is thould not be drawn.

The instant oceasion is not the first on which men of high authority have mistaken a law of evidence for substantive law. The thesis of "objective liability" in the criminal law was propounded by Holmes in his Common Law. In Holmes' view,

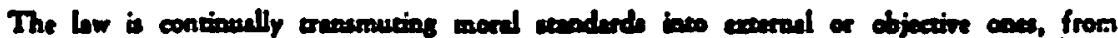

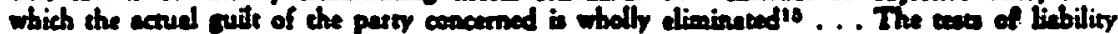

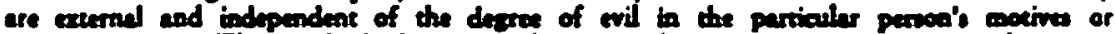

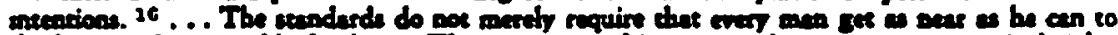

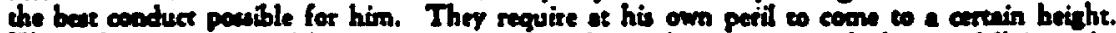

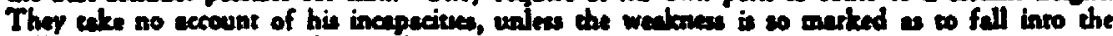

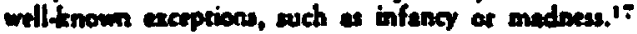

(2\{1954] Crim. LR. 216.

21(1950), 66 T.L.R. 735, at \%38.

10(1936), I1s C.C.C. 203, at 213

16The Common Low, p. 38.

1976id.. p. 50 .

1rlbid., p. 50. 
And later, dealing with the specific crime of murder:

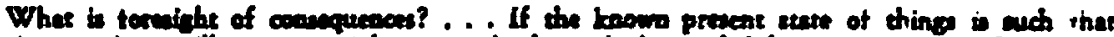
the ear doan will ver cortainly cuuse deach, and the perbability is a morter of common knowlater, cese tho does the ece boowing the present atsre of thines, is guiley of murdes and

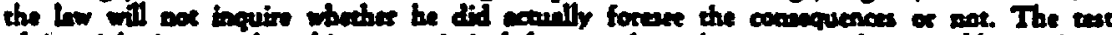
of loresitht is nox thet thin very criminal forasin, but what a men of reasonable prudence forenum.ts

Holmea' thexis of objective liability and the $W$ ard case stanc' well rogether But it is significant that Holmes wrote The Common Low in 1881, that his theory has bees politely ignosed by other writers, and that judicial opinion has been consistently opposed to it, at least until this late date. Jerome Hall, in his text Principles of Criminal Law, devoted a complete chapter to an examination of objective linbility, and in the coure of refuting the theory, stated that its basis lies in the asoumption that the foundation of criminal law is expediency, not moral culpability." Appareatly, the chief reason for the adoption of ex. pediency as an underlying principle of criminal law lies in the difficultey of discovering a man's true state of mind. Those who propound objective lin. bility in effect asert that because it is 200 difficule to diecover the true sta!: of a man's mind, we will ignore it, and apply the objective teat ex post facts, and thes "formulate" a state of mind. But Bowea L. J. was not impressed with the difficulty and he axid in one cave, "the state of a man's mind is as mucl s fact as the state of his digeation"," and in another case:"

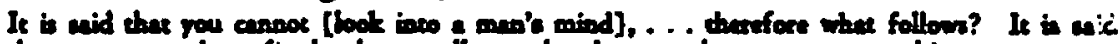

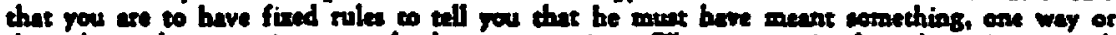
the ocher, when certein exernal phenomenn aries. The anower is thet there is no euch

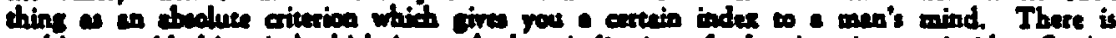

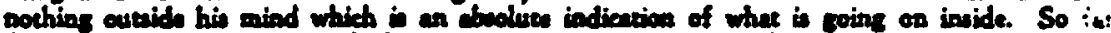

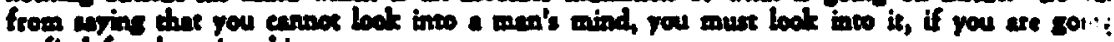
to find frasd arint bim.

If this reasoning is applicable in a mere case of fraud, would it not be even more 80 in the case of murder?

Hall points out that Holmes has confused the law of evidence with substantive law: ${ }^{22}$

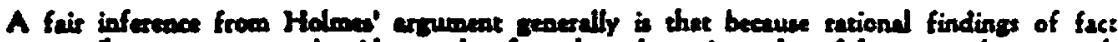

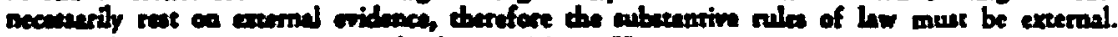
Holdsworth comes 10 grips with the problem: ${ }^{23}$

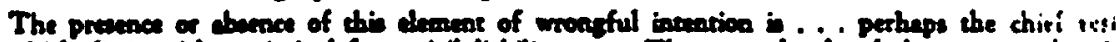

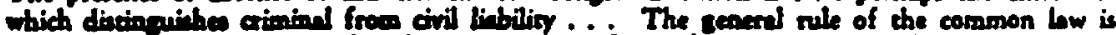

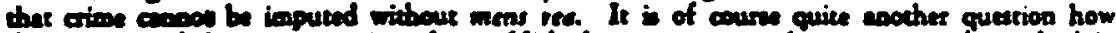

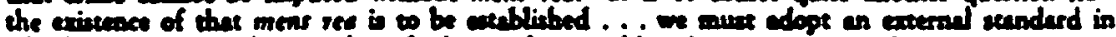
adjudicating upen the wright of the evidenes edduced to prove or dippreve mens ree.

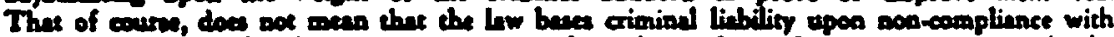

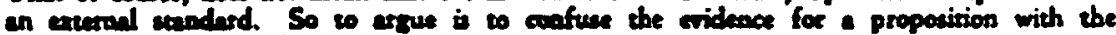
prepenition preved by that evidence.

It is submitted that these objections to Holmes' theory are valid, and since the Ward case proceeds on the besis of objective liability they apply here as well.

\footnotetext{
solbid., p. 53.

20 At p. 181.

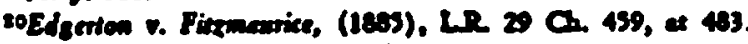

si Anges v. Cifford [1891] 2 Ch 490471 ,

saprinciple of Criminel Lew, D. 176.

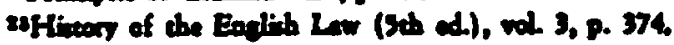


$\therefore$ iv summitted that the leamed Lord Justices in the Ward case did no: in $:$ segard to the development of mens rea in the law of murder, and that in: -inciple of the case hampers such progressive development. J.W.C. Turner ". Hussell on Crime" sets out the modern view of the mens rea tequired; surder after tracing its historical development: ${ }^{\text {-3 }}$

The new ense consiss in the requirement thet the ccaued person, when pursuing the lint of conduct. . . which resuleed in the herm for wich be is etherged, must have beet. owere that such harmful consequences would or could follow.

Kenny points out that there are three stages of development in the historv ot nens rea in murder.

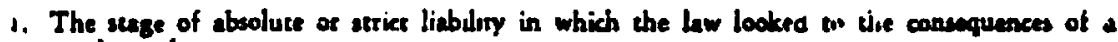
man's conduca.

2. The stage in which the medieval applied an objective moral rent to the conduct leading to those conseguences.

3. The stage, ... when the law came to edopt a mbjective cent: that is to sey, it now looked ptumarily at the attitude of the defendent's mind which inspised his conduct.

It is apparent that the approarl, has become increasingly more subtle over the vears: the courts become bolder, and more and more they attempt to discover winat lay in the accused's mind when he did the act. Thev were aided in this by a concurtent development in the law of evidence; i.e. the accused became comperent to give evidence at his own trial. The $\mathrm{W}$ ard case ignores this development, and therefore it is submitted that it is an unwarranted throw-back to an earlier stage of our lau.

It is submitted that objective liability, or the idea that "all must be treated alake" ought never to become a principle of the criminal law. As Hall points iout" the basis of this theory is expediency, and it is submitced that expedieney is an unwiorthy guide in that part of the law which, more than any other, ought to be humane. It is inhuman to sentence $2 \operatorname{man}$ to death when there is nr guilty consciouness on his part attaching to the act complained of. It is onls the sceptical realism of the objective approach that allows this dire tesult, and it is submitted that sceptical realism ought not to be given precedence over humanity. It is submitted that the $W$ ard case ought to be rejected in Canada, and that full effect be given to the principle actus non jarit reum, nisi mens sit ria at least in the law of murder.

\author{
- Donald H. Ostry \\ Third Year Law
}

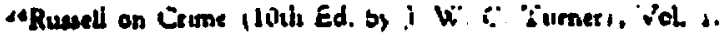

"At p. 3!

20keany's Outlunes of Cruminal Lan, (J6w Ea.i. - is:

"Prsocinles of Cromarial Lan, $p$. in 